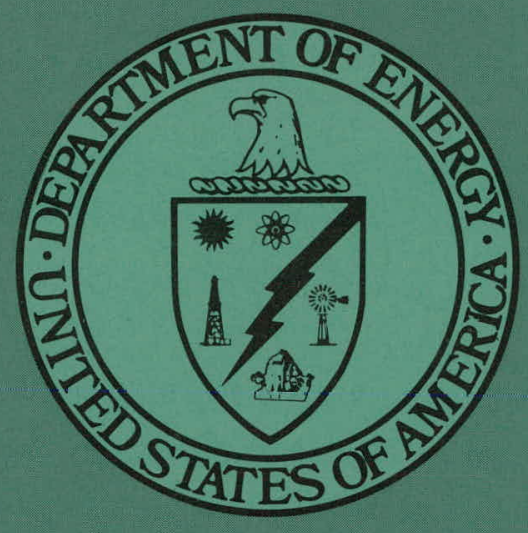

BERC/RI-78/11

THE BERC RE-REFINING PROCESS: COMPARISON OF HYDROFINISHING VERSUS CLAY CONTACTING

By

Richard J. Bigda \& Associates

Prepared for DOE Under P.O. No. EY-77-X-19-0237

Date Published-July 1978

Bartlesville Energy Research Center

Department of Energy

Bartlesville, Oklahoma

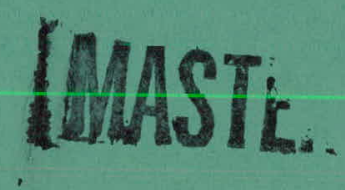




\section{DISCLAIMER}

This report was prepared as an account of work sponsored by an agency of the United States Government. Neither the United States Government nor any agency Thereof, nor any of their employees, makes any warranty, express or implied, or assumes any legal liability or responsibility for the accuracy, completeness, or usefulness of any information, apparatus, product, or process disclosed, or represents that its use would not infringe privately owned rights. Reference herein to any specific commercial product, process, or service by trade name, trademark, manufacturer, or otherwise does not necessarily constitute or imply its endorsement, recommendation, or favoring by the United States Government or any agency thereof. The views and opinions of authors expressed herein do not necessarily state or reflect those of the United States Government or any agency thereof. 


\section{DISCLAIMER}

Portions of this document may be illegible in electronic image products. Images are produced from the best available original document. 


\section{NOTICE}

This report was prepared as an account of work sponsored by the United States Government. Neither the United States nor the United States Department of Energy, nor any of their employees, nor any of their contractors, subcontractors, or their employees, makes any warranty, express or implied, or assumes any legal liability or responsibility for the accuracy, completeness or usefulness of any information, apparatus, product or process disclosed, or represents that its use would not infringe privately owned rights.

This report has been produced directly from the best available copy.

Available from the National Technical Information Service, U.S. Department of Commerce, Springfield, Virginia 22161.

Price: Paper Copy $\$ 4.00$

Microfiche $\$ 3.00$ 


\title{
THE BERC RE-REFINING PROCESS: COMPARISON OF HYDROFINISHING VERSUS CLAY CONTACTING
}

\section{By}

Richard J. Bigda \& Associates

Tulsa, Oklahoma

\begin{abstract}
Engineering and design studies
Prepared for the Department of Energy

Under Purchase Order No. EY-77-X-19-0237
\end{abstract}

Technical Project Officer

Marvin L. Whisman

Bartlesville Energy Research Center

Bartlesville, Oklahoma

Date Submitted-March 1978

Date Published-July 1978
This report was prepared as an account of work sponsored by the United Stotes Govemment. Neither the United Sutes nor the United States Department of Enerd ster Energy, nos any of their employess, nor any of their contractors, subcomsactors, or their employecs, makes any warranty, express or implied, or assumes any legal liability or responsibility for the aceuracy, completeness or usefulness of any information, apparatus, product or process disclosed, or represents that its use would not infringe privately owned rights.

\footnotetext{
U.E. DEPARTMENT OF ENERGY

TECHNICAL INFORMATION CENTER
} 
The BERC Re-refining. Process; Comparison of Hydrofinishing versus Clay contacting

Analysis of the Hydrofinishing of solventTreated Used Lube oils

Comparison of Acid/Clay, BERC Hydrogenation and BERC Clay Contacting Methods of lube oil Re-refining

References

\section{IIST OF EXHIBITS}

1. BERC Re-refining Process

2. BERC Re-refining Process substituting Hydrofinishing step

3. BERC Process with Hydrotreating, Predesign Process Equipment Costs

4. Capital Investment Comparison

5. Labor Requirements

6. Manufacturing Cost per Day

7. Comparison of BERC clay Contacting, Hydrofinishing and Acid/Clay Methods of Lube Oil Re-refining 


\section{EXECUTIVE SUMMARY}

To produce high quality lubricating oil from used oil requires the complete removal of all contaminants. The BERC process accomplishes this through a combination of solvent extraction followed by vacuum distillation. The distilled oil may still possess unacceptable levels of color and odor. A final finishing step consisting of either clay contacting or treatment with hydrogen' will result in specification grade motor oils. Both hydrofinishing and clay contacting have advantages and operating differences. Handing of solid clay and disposing of an oil-soaked spent clay present processing problems, but its use is easily controlled and little skill is required. Hydrofinishing eliminates the solids handing problems, but introduces a sophisticated high pressure unit operation into the traditionally simple re-refining industry. This paper compares the processing advantages and problems and, by economic analysis, demonstrates that the costs of production of either finishing step are nearly the same about 40 per gallon. Variables such as clay and hydrogen costs and waste clay disposal costs are determining factors. Capital costs for a BERC unit with clay contacting is about $\$ 100,000$, or 38 cheaper. More highly skilled labor is required for the high pressure hydrofinishing step. The options presented will aid the re-refiners in designing a new facility. 


\section{THE BERC RE-REFINING PROCESS: COMPARISON \\ OF HYDROFINISHING VERSUS CLAY CONTACTING}

\section{IN TRODUCTION:}

Over the past several years re-refining research has developed new techniques for reclaiming used lubricating oils. Independent re-refiners have been operating with acid/ clay technology for the most part during the past thirty years, but little effort until now has been applied to this process by major laboratories. Bartlesville Energy Research Center (BERC) has developed a new process to reclaim used lube oils, using a solvent extraction process, followed by vacuum distillation and a final clay contacting or hydrogenation finishing step. Clay contacting was a standard procedure used by major lube oil producers until the 1960's when it was found that by hydrotreating the virgin lube stocks, clay contacting could be eliminated. A ready source of hydrogen existed at the refineries and it was more economical to use their own by-product, hydrogen, than to buy clay, cope with a solids handing problem, and contend with the disposal of the spent clay. To the best of this author's knowledge the hydrofinishing of used lube oils is not now a part of any commercial process in the United states or Europe, although it has been proposed by several in the industry. It has been suggested by such advocates that using hydrogen in place of clay would produce a cheaper finished lube oil with superior quality. The purpose of this report is to explore this contention and to determine the cost factors and operating variables associated with hydrofinishing.

In preparing cost comparisons and analyzing operating variables, it is necessary to put the operations to be compared on the same basis. Therefore, a hypothetical system must be devised to compare the operating process variations and their economic effect. In this case the basis is an earlier report prepared for the Bartlesvilie Energy Research Center, Department of Energy, entitled "predesign Cost Estimate for Re-refined lube oil plant"l. In this earlier document costs associated with the BERC solvent refining process were detailed and equipment and operating cost estimates developed. This predesign report is a comparison between the two possible lube finishing steps, clay contacting or hydrofinishing.

Hydrofinishing is inherently attractive because it eliminates the necessity to purchase clay and the labor intensive steps of charging the clay to the contacting vessel, 
filtering it, and disposing of a solid waste material, the oily spent clay. A messy time-consuming step, that of filtering hot oily clay, is eliminated. Gaseous hydrogen flowing through a catalytic reactor followed by only minor filtration appears at first to be a more desirable finishing step, however, some of the problems associated with hydrogenation will be delineated in this document. This comparison can serve as a starting point for considering the advantages and disadvantages of both processes. No effort is made in this analysis to determine the advantages of hydrotreating $r$ aw used motor oils as an alternative process to the BERC solvent re-refining, acid/clay contacting, or other re-refining processes. In this case the raw used oil is solvent extracted first, then vacuum distilled and treated with hydrogen. 
ANALYSIS OF THE HYDROFINISHING OF SOLVENT-TREATED USED LUBE OILS

In the BERC solvent re-refining process used motor oils are first dehydrated and stripped of light hydrocarbons in a packed column. This process is described in the Bureau of Mines Report of Investigations $7925^{2}$. The dehydrated sludge-containing oil is then treated with a $3: 1$ mixture of mixed solvents (butyl alcohol, isopropyl alcohol and methyl ethyl ketonel. The solvent-used oil mixture is allowed to settle and the sludge is drawn off the bottom of the conical settling tanks or centrifuged to recover oil and solvent. The solvent is then recovered from the lube oil by distillation. In the BERC process the solvent is recycled and the extracted lube oil vacuum distilled to produce specification lube oil blending stocks. These blending stocks are contacted with absorbent clay to remove color bodies and improve odor. After the clay and hot lube oil have been contacted, the mixture must be filtered to produce a finished lube stock having qualities similar to virgin lube stocks.

In this report economic and technical comparison is made with the BERC process as it has been developed and by substituting hydrofinishing for the clay contacting step. Our concept of the BERC process is presented in the flow sheet of Exhibit 1. If hydrofinishing were substituted for clay contacting, some equipment would be eliminated and new items added. The clay contacting apparatus and the larger more expensive filtering apparatus would be removed, but in their place a high pressure catalytic reactor would be added for mild hydrotreating of lubricating oils. A mixture of the oil and hydrogen is passed through a heater, probably a direct fired furnace, to bring it up to an operating temperature of $480^{\circ}$ to $600^{\circ} \mathrm{F}$. Depending on the process chosen, the operating pressures would be between 400 and 1,000 psig. Generally a nickel-molybdenum or cobalt-molybdenum type catalyst would be used to promote the hydrogenation reaction. After passing through the furnace or heater the high pressure fluid is pumped into the reactor at the top allowing a downward flow through the catalyst bed. $3,4,5,6$ Hydrogenation promotes color and odor improvement, neutralization and desulfurization.

After reaction the oil is separated from the gas in two stages. The offgas can be recycled or used as a fuel gas. Following gas separation the oil is then steam stripped and dried in a vacuum column to remove water and light distillates. The catalyst is required to be regenerated on occasion and this can usually be accomplished by a simple in situ burn off with a steam-air mixture. The advantages of this mild hydrotreating are the elimination of the clay treatment, a 


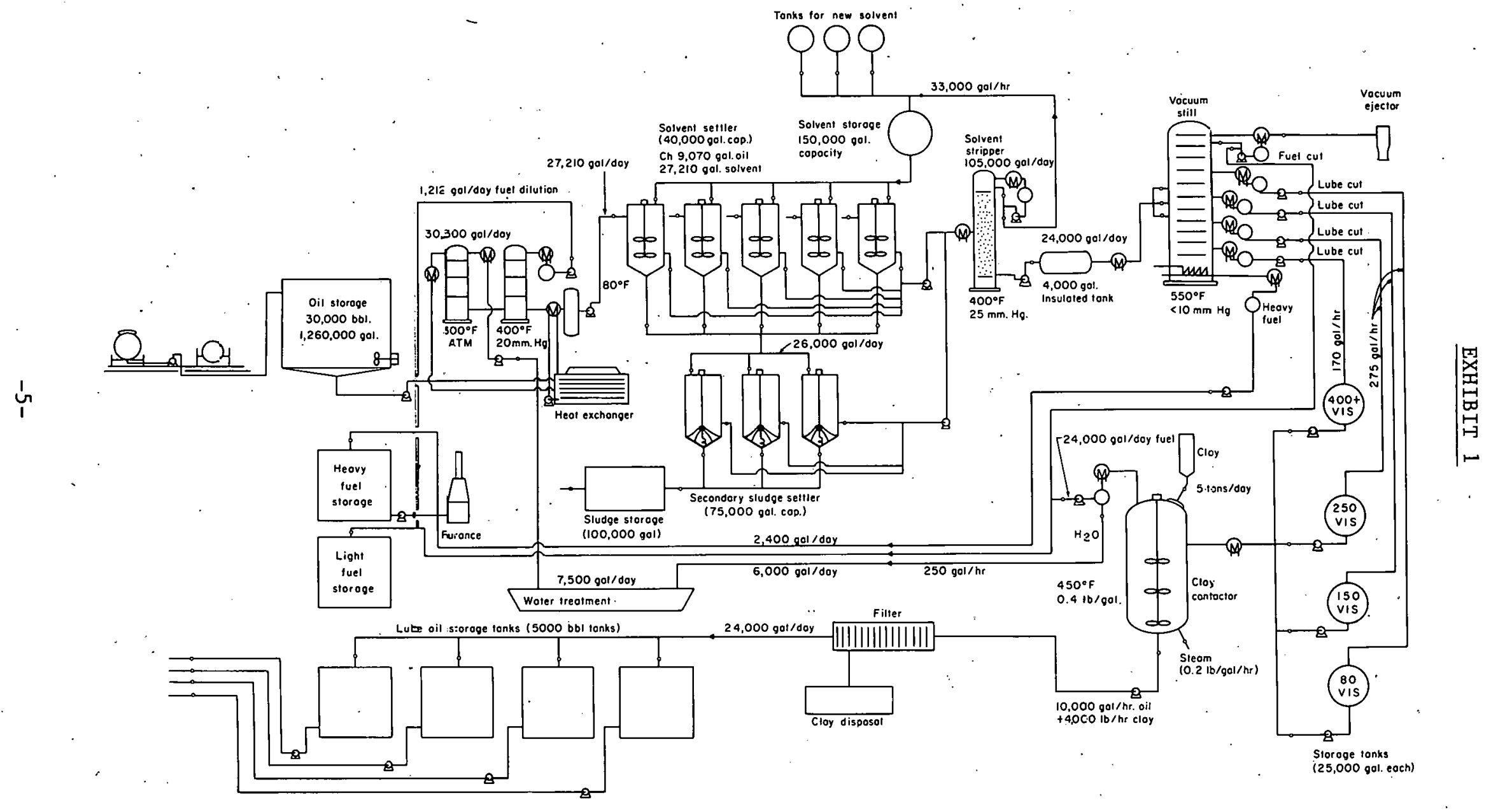


comparatively simple and continuous operation, and reduction of manual labor required to charge the clay contactor and operate the filter press. product yields may be improved and the clay disposal problem is eliminated. A filtering step may still be involved, but this merely involves polishing the product and would employ. only a small, inexpensive type filter. Exhibit 2 is a flow sheet showing the BERC process with mild hydrotreating substituted for the clay contacting operation.

\section{PREDESIGN PROCESS EQUIPMENT COSTS:}

An equipment list is included in Exhibit 3. It indicates the remaining equipment is identical to that in the 10million-gallon-per-year plant described in the original predesign study (Exhibit 1), except for a larger furnace since additional heat will be required for the hydrogenation. Naturally the hydrogenation equipment including another steam stripper and vacuum dryer is substituted for the clay contacting and heavy duty filtering apparatus. The difference in capital costs is estimated to be approximately $\$ 116,000$ more for the hydrotreating process versus the clay contacting operation. The clay contacting plant is estimated to cost $\$ 1,963,000$, while the hydrogenation system may cost $\$ 2,079,000$ (note Exhibit 4). If a cheaper batch type filter were used instead of the rotary filter provided for in the original BERC design, the BERC capital costs with clay contacting could be considerably less.

\section{MANUFACTURING COSTS:}

Because of the increased sophistication of the operation, it is suggested that an additional skilled man be added to operate the hydrogenation section of the plant. More careful attention will have to be paid to this high pressure operation than for the relatively simple clay contacting. Labor cost estimates are shown at $\$ 226,400$ per year in Exhibit 5. Most references suggest that labor requirements will be reduced, but this will be true only for much larger plants (10 to 20 times larger). Almost $\$ 660$ worth of clay per day was used in the original process, and hydrogen, the replacement for the clay, is estimated to cost only $\$ 116$ a day, but an additional charge of $\$ 1,050$ per month is made by the hydrogen supplier to defray the costs of on-site hydrogen storage, either cryogenic or steel cylinders. This amounts to $\$ 36$ a day, applied to indirect manufacturing costs. Based on a 2.0,570-galion-per-day production of finished lube oils, the cost per galion for the hydrotreated oils would approximate $40 \%$, which is competitive with clay contacting at an estimated cost of 41 \&, as noted in Exhibit 6 . With the capital and operating costs so nearly the same for either option, 


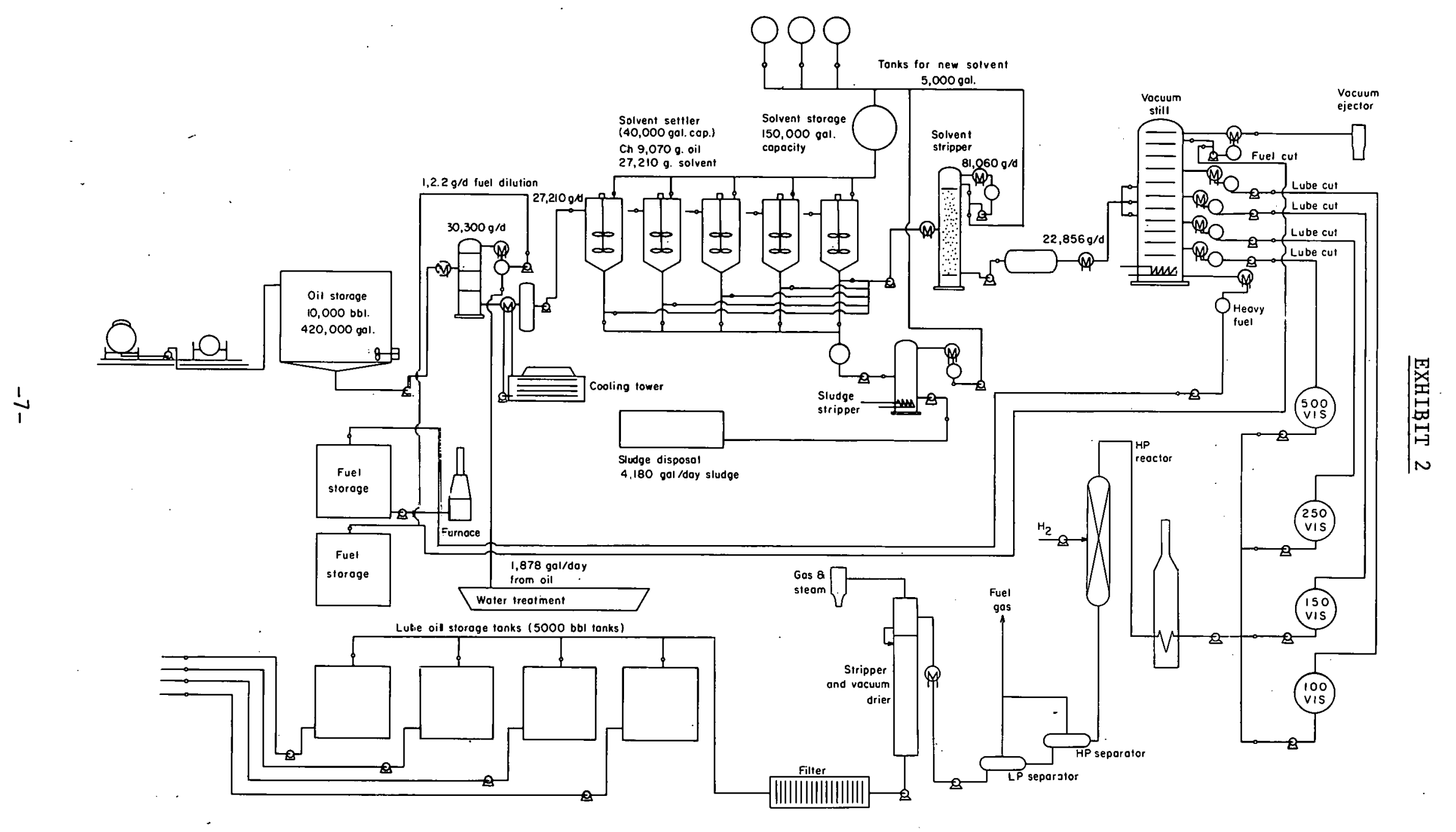

BER RE-REFINING PROCESS SUBSTITUTING HYDROFINISHING STEP 
BERC PROCESS WITH HYDROTREATING PREDESIGN PROCESS EQUIPMENT COSTS

Item of Eguipment

oil Unloading

Oil storage Tank, 2

Side Mixers, 2

Unloading Pump
Specifications

200,000

$5 \mathrm{hp}$

$100 \mathrm{gpm}, 1.5 \mathrm{hp}$
Estimated

Erected

Cost, Each Total Cost

$\$ 45,000$

3.000

2,600

$\$ 90,000$

6,000

$\frac{2,600}{\$ \quad 98,600}$

$1,900 \$ 1,900$

15.800

15,800
$3 \mathrm{gpm}$

511

40 ft 2

$100 \mathrm{~g}$

Lt. Fuel pump

Crude Lube Cooler

25 gpm

$330 \mathrm{ft}^{2}$

Fuel Flash Drum

Condenser

Accumulator

Solvent Treatment

\section{oil to Treater pump \\ solvent Pump to \\ Treater}

solvent settler, 4

Agitators, 5
5,000

2,500

1,000

800

21,300

$3 \mathrm{ft} \times 5 \mathrm{ft}$
$20 \mathrm{gpm}$

$60 \mathrm{gpm}$

$40,000 \mathrm{~g}$

$3 \mathrm{hp}$

\begin{tabular}{rrr}
1,900 & $\$$ & 1,900 \\
2,500 & 2,500 \\
20,000 & 80,000 \\
3,200 & 16,000 \\
\cline { 2 - 2 } & & $\$ 100,400$
\end{tabular}

2,600

$\$$

2,600

30,300

30,300

$4 \mathrm{ft}$ dia. $x 30 \mathrm{ft}$ packed Berl

saddles

30,000

16,500

1,000

70,000

2,600

1,900

5.000

2,500

1,000 800

$\frac{21,300}{\$ \quad 48,300}$

$2700 \mathrm{ft}^{2}$

$90 \mathrm{gpm}$

$20 \mathrm{gpm}$

$\begin{array}{r}30,000 \\ 16,500 \\ 1,000 \\ 70,000 \\ 2,600 \\ 1,900 \\ \hline 154,900\end{array}$

16.500

1,000

2,600

$\frac{1,900}{\$ 154,900}$

Pump stripper Bottoms 
EXHIBIT 3 (Continued)

BERC PROCESS WITH HYDROTREATING

PREDESIGN PROCESS EQUIPMENT COSTS

\section{Page $\cdot 2$}

Estimated

Erected

Item of Eguipment

Sludge stripper

Sludge Accumulator

sludge Pump to

stripper

sludge Pump

sludge Overhead

Condenser

Accumulator

sludge-solvent Pump

Reboiler

sludge cooler

sludge stripper
Specifications

Cost, Each
Total cost

$\$ 3,000 \$ \$ 3,000$

$80 \mathrm{gpm}$

$80 \mathrm{gpm}$

3,000

3,000

3,000

3,000

$6 f t^{2}$

$100 \mathrm{~g}$

$3 \mathrm{gpm}$

$107 \mathrm{ft} \mathrm{t}^{2}$

2 ft $x 5$ ft packed
500

800

6.800

7,300

500

1.000

800

6,800

7,300

2.900

Vacuum Distillation

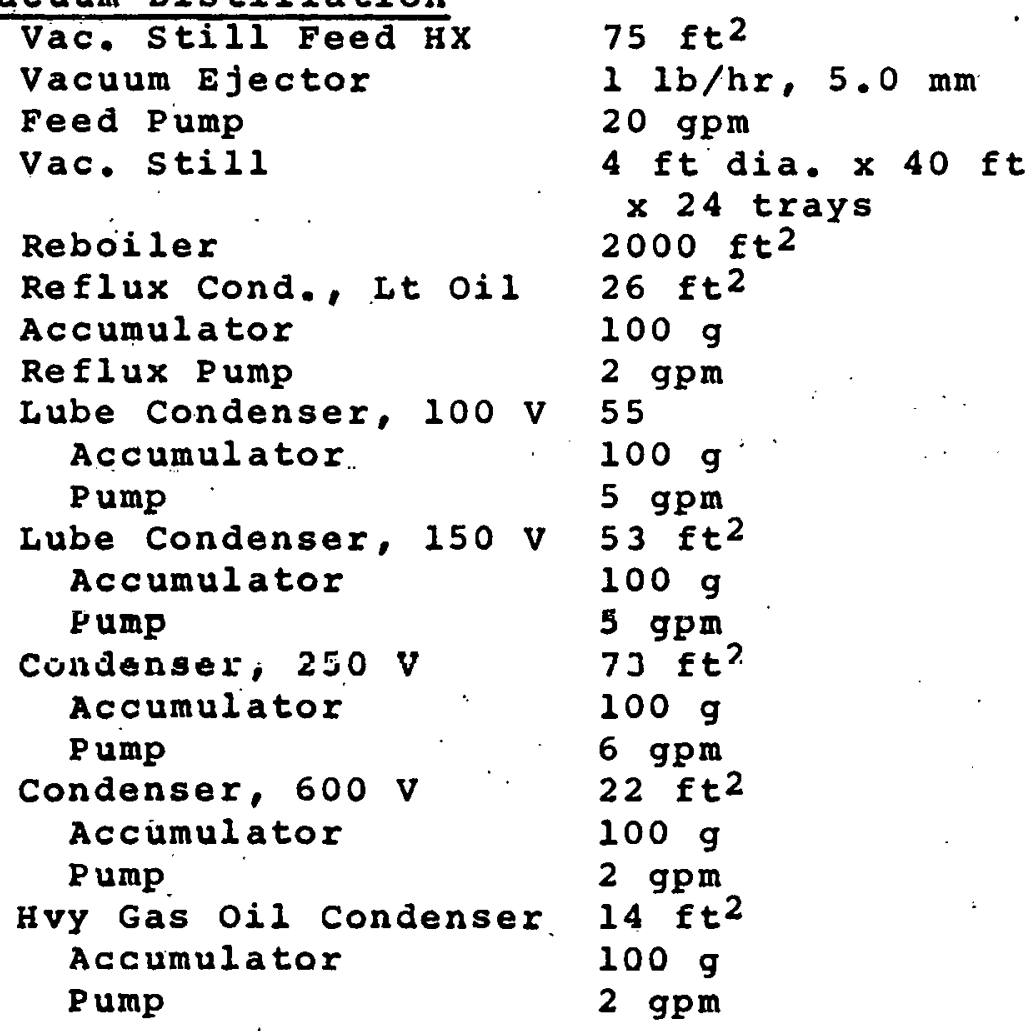

4,800

3,500

1,900

82,000

51,000

1,500

1,000

800

3,500

1,000

800

3,500

1,000

800

4,000

1,000

800

1.500

1.000

1.000

700

1.000

1,200
4,800

3.500

1,900

82,000

51,000

1,500

1,000

800

3,500

1,000

800

3,500

1,000

800

4,800

1,000

800

1,500

1,000

1,000

700

1,000

$\frac{1,200}{1,100}$ 
BERC PROCESS WITH HYDROTREATING

PREDESIGN PROCESS EQUIPMENT COSTS

Page 3

\section{Item of Equipment}

Intermediate Lube storage

$\begin{array}{ccc}\text { Storage tank, } 100 \mathrm{~V} & 25,000 \mathrm{~g} \\ \text { Pump } & & 90 \mathrm{gpm} \\ \text { Storage Tank, } 150 \mathrm{~V} & 25,000 \mathrm{~g} \\ \text { Pump } & & 90 \mathrm{gpm} \\ \text { Storage Tank, } 250 \mathrm{~V} & 25,000 \\ \text { Pump } & & 90 \mathrm{gpm} \\ \text { Storage Tank, } 600 \mathrm{~V} & 25,000 \mathrm{~g} \\ \text { Pump } & & 90 \mathrm{gpm}\end{array}$

Reactor

Catalyst

P ump

$\mathrm{H}_{2}$ Compressor

Reactior

\section{specifications}

\section{Estimated}

Erected

Cost, Each Total cost

$\begin{array}{lll}8,000 & \$ & 8,000 \\ 2,600 & & 2,600 \\ 8,000 & & 8,000 \\ 2,800 & & 2,800 \\ 8,000 & & 8,000 \\ 2,800 & & 2,800 \\ 8,000 & & 8,000 \\ 2,800 & & 2,800 \\ & & 43,000\end{array}$

$1000 \mathrm{psi}, 15 \mathrm{gpm}$

$\$$

$50 \mathrm{hp}, 2$ stage,

$208 \mathrm{scf} / \mathrm{in}$.

$4 \mathrm{ft} \times 10 \mathrm{ft}$

vertical, 1000

psi

\begin{tabular}{|c|c|c|}
\hline $\begin{array}{r}3,400 \\
10,200\end{array}$ & $\$$ & $\begin{array}{r}3,400 \\
10,200\end{array}$ \\
\hline 60,000 & & 60,00 \\
\hline 43,000 & & 43.000 \\
\hline
\end{tabular}

HP and IP Separators

HP

$1000 \mathrm{pgi}, 500 \mathrm{gal}$

25,440

14,755

500 psi. 500 gal

\section{stripper and Vac.}

\section{Drier}

\section{Tower}

Vac. Ejector

Feed Heater

Stripper Feed Pump

Filter

Filter Pump

$3 \mathrm{ft} \times 20 \mathrm{ft}$

$75 \mathrm{ft}^{2}$

$20 \mathrm{gpm}$

$100 \mathrm{ft}^{2}$

$20 \mathrm{gpm}$
35,800

3,500

4,800

1,900

17,000

1,900

$\begin{array}{r}35,800 \\ 3,500 \\ 4,800 \\ 1,900 \\ 17,000 \\ 1,900 \\ \hline \$ 64,900\end{array}$


BERC PROCESS WITH HYDROTREATING

$\frac{\text { PREDESIGN PROCESS EQUIPMENT COSTS }}{\text { Page } 4}$

Item of Equipment

Finished Lube and

solvent storage.

$\begin{array}{ll}\text { Lube Storage Tanks, } 4 & 200,000 \mathrm{~g} \\ \text { Pumps, 4 } & 100 \mathrm{gpm} \\ \text { Fuel storage, 3 } & 40,000 \mathrm{~g} \\ \text { Pump Loading } & 100 \mathrm{gpm} \\ \text { Solvent storage } & 150,000 \mathrm{~g} \\ \text { Separate solvents, } 3, & 10,000 \mathrm{~g} \\ \text { Pump } & 60 \mathrm{gpm}\end{array}$

Each Separate

Boiler, Complete

Hot oil Furnace,

Complete Direct

Cooling Water,

Complete

$1400 \mathrm{gpm}$,
$14,000,000$
Btu/hr

$\mathrm{lb} / \mathrm{hr}$

$700^{\circ} \mathrm{F}$
Estimated

Erected

specifications Cost, Each Total Cost

$\begin{array}{rr}\$ 39,000 & \$ 156,000 \\ 2,600 & 10,400 \\ 9,600 & 27,000 \\ 2,600 & 2,600 \\ 28,000 & 28,000 \\ 3,500 & 10,500 \\ 2,400 & 2,400 \\ & \$ 236,900\end{array}$

200 psi, 22,000

$134,000 \$ 134,000$

$30 \mathrm{M} \mathrm{Btu/hr}$,

$410,300 \$ 410,300$

$221,000 \$ 221,000$

Water Treatment

Clay Disposal

sluage Disposal

TOTAL EQUIPMENT COST

$\$ 1,870,000$ 
Installed Equipment Piping

Building, $\$ 20 / f t^{2} \times 1000 \mathrm{ft}^{2}$ Land \& Improvements

Utilities

TOTAL

Engineering \& Construction, 108

TOTAL FIXED $\cos T$
Hydrogenation contacting

$\$ 1,870,000$

$\$ 1,765,200$

20,000

Unknown

Unknown

$\$ 1,890,000$

20,000

Unknown

Unknown

$\$ 1,785,200$

189.000

178.000

$\$ 2,079,000$

$\$ 1,963,000$

Working Capital:

Raw Material Inventory, one mo.

(c) $\$ 0.15 / 9$

solvent Inventory, full tanks

clay Inventory

Re-refined $0 i l$ Inventory, one mo. a $\$ 0.40 / 9$

Extended Credit, one mo. sales

a cost

Available Cash, one mo. mfg.

expense

$\$ \quad 135,000$

215.800

$\$ 135,000$

215,800

- 20,000

TOTAL WORKING CAPITAL

240,000

240,000

240,000

240,000

75,000

75,000

$\$ 905,800$

$\$ 925,800$

TOTAL CAPITAL REQUIRED

$\$ 2,984,800$

$\$ 2,888,800$ 


\section{EXHIBIT 5}

LABOR REQUIREMENTS

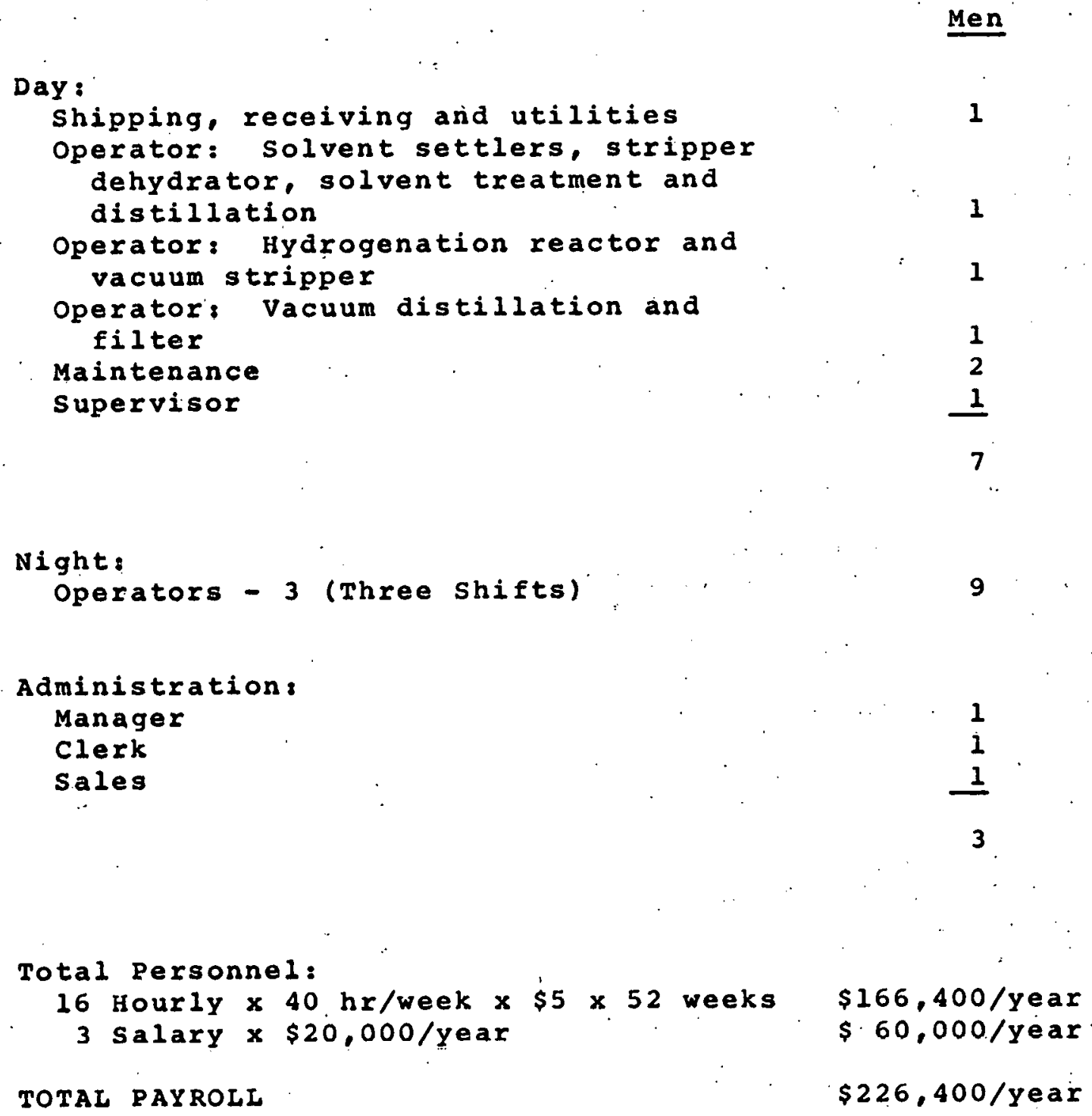

Total Personnel:

16 Hourly $\times 40 \mathrm{hr} /$ week $\times \$ 5 \times 52$ weeks 3 salary $x \$ 20,000 /$ year 
Hydrogenation

Used Oil. a $\$ 0.15 / \mathrm{g}, 30,000 \mathrm{~g}$

solvent, $410 \mathrm{~g} / \mathrm{d}$ loss @ $\$ 1.21 / \mathrm{g}$

$\mathrm{H} 2,0.6 \mathrm{SCF} / \mathrm{g}$

Clay a $\$ 160 / \mathrm{T}, 0.4 \mathrm{lb} / \mathrm{g}$

Catalyst, I $\& / B$

Sludge Disposal

Supplies, 15 of Maintenance

Costs

Labor a $\$ 5 / \mathrm{hr}$

Supervision: See Administration

Utilities, estimated

Maintenance, 58 of Fixed Capital

DIRECT MANUFACTURING COST

Overhead, 508 of Labox

Laboratory, 108 of Labor

Shipping - unknown

H2 Equipment Rental and Maintenance*

INDIRECT MANUFACTURING COST

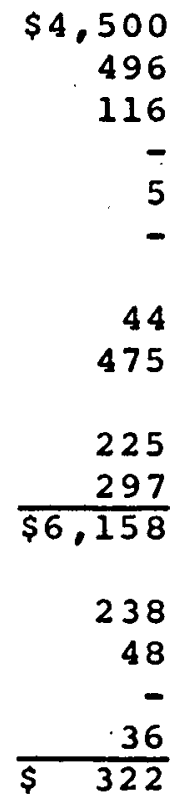

595

561

Capital

property Taxes, 28 of Fixed

Capital

Insurance, 18 of Fixed Capital

FIXED MANUFACTURING COST

Administration \& Sales

Expense: See Overhead

Finance, 108 Total Capital

GENERAL EXPENSE

TOTAL MANUFACTURING COST/DAY

$20,570 \mathrm{~g} / \mathrm{d}, 708$ conversion,

cost/galion

$\$ 214$

\section{2}

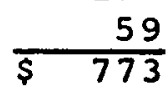

56

$\$ 729$

171

171

$\frac{854}{\$ 1.025}$

823

$\$ 8,278$

$\$ 8,520$

$\$ \quad 0.402$

$\$$
Clay

Contacting

$\$ 4,500$

496

658

100

42.

357

150

$\frac{280}{\$ 6,583}$

178

36

0.414

*In the most economical method of $\mathrm{H}_{2}$ handling, the equipment remains the property of the vendor, and the vendor has responsibility for maintenance of the equipment. For this service, there is a standard fee of $\$ 1,050$ per month, regardless of the volume of $\mathrm{H}_{2}$ used. This charge is uniform throughout the industry. 
one has to consider carefully the advantages and disadvantages of each mode of operation and determine what would suit them best.

ADVANTAGES AND PROBLEMS ASSOCIATED WITH HYDROTREATING VERSUS CLAY CONTACTING:

since the capital and operating costs are very similar for the two types of manufacturing schemes, careful attention should be given to the advantages and problems associated with each of the techniques. The advantages and disadvantages to using hydrotreating are noted with attention called to certain unresolved problems which may not be demonstrated one way or another until a commercial unit is in actual operation.

\section{Advantages}

- Elimination of oily clay disposal problems.

- Reduced solids handing - clay in and out.

- Filtration problems minimized.

\section{Disadvantages}

- slightly higher capital costs for hydrogenation equipment.

- Advanced technology required.

- Elevated temperatures and pressures pose dangerous operating conditions.

- Explosive hydrogen stored on plant site.

- Cryogenic or high pressure steel storage cylinders required.

- Cryoganic hydrogen storage requires additional attentinn.

- Plant shutdowns may result in excessive hydrogen losses from cryogenic storage unit at approximately 894 per 100 standard cubic feet.

- Additional energy will be required to maintain the high temperatures and high pressures involved in hydrogenation versus lower temperature atmospheric clay contacting. This is reflected in higher utility costs. 
- Increased maintenance costs due to the required care of high pressure equipment.

- Addional stripper and drying tower operation.

- Decreased operating flexibility, i.e., flow rates must be relatively constant, which calls for smoother operation of the entire plant.

Uniresolved Problems

Since used lube oils contain heavy metals and uncontrollable contaminants, it may be that such materials will poison the catalyst. The nickel-molybdenum catalyst selis for approximately $\$ 2.00$ a pound and should the catalyst be poisoned, recharging would cost approximately $\$ 3,400$ for the catalyst plus the cost of recharging the reactor. Further, it has been demonstrated thathydrofinishing will in fact efficiently improve the color, odor, stability and overall quality of the used oil. Clay has been used commercially to achieve this product quality and it is easily controlled. For example, the quality of the finished oil is adjusted by the temperature, quantity and quality of the clay and time of contacting. simple physical tests can be performed during the batching of the oil to determine when it has reached the appropriate quality. Hydrogenation is a continuous process which would have to be constantly monitored to insure that a quality product was being produced. If it does not function properly the entire stream must be recycled back to the hydrogenation preheat furnace, which will cause operating difficulties for the stripper and vacuum distillation units.

For small operators, those interested in employing used process equipment, the probability of finding a suitable secondhand hydrogen reaction system is very low; therefore, should such a unit be installed it would likely have to be engineered and fabricated specifically to fit the characteristics of the plant. It is strongly urged that a skilled refinery operator be employed for the operation of the hydrogenation unit. Additional instrumentation and safeguards must be considered. Finally, availability of hydrogen may be a problem as there are few hydrogen-producing facilities producing for the merchant market. Should the re-refiner be located near a crude oil refinery, hydrogen or hydrogenrich gas may be available via pipeline at a more attractive price.

Merchant hydrogen is available from only a few locations in the U.S. and prices will be f.o.b. shipping point. Therefore, some areas would be disadvantaged by having to 
use $\mathrm{H}_{2}$. A plant located near a hydrogen generator such as a refinery could purchase $\mathrm{H}_{2}$ via pipeline on demand at very reasonable prices compared to the plant that had to buy liquid H2. High quality clay, too, will vary in cost depending upon distance. The costs in this report are based upon prices quoted Bartlesville, Oklahoma. Estimating that $\$ 192$ per day has been allotted for clay costs and $\$ 1.16 \mathrm{H}_{2}+\$ 36$ storage $+\$ 5$ catalyst $=\$ 157$ per day for hydrogenation, it will not take too much (\$35) refinement to change the advantage in favor of clay contacting. Yields may be slightly improved if hydrofinishing is employed since oil will not be lost by absorption on the clay. An improved yield would lower the processing cost per gallon. A lo yield variation would change the cost by $0.5 \%$ per gallon. 
Exhibit 7 indicates the major operating costs of the process, acid/clay contacting, with the BERC clay contacting and the BERC hydrogenation processes. It can be noted that on the same basis as described in a comparison report issued by BERC 7 which shows that because of the cost of the acid and clay that this process does appear to be the most costly on a cents-per-galion basis, even though the capital costs are less. The solvent process developed by BERC with or without hydrogenation is about 208 cheaper than the acid/clay process. Careful consideration should be given by the potential re-refiner to the advantages, disadvantages and problems inherent in each process, and these series of papers may aid in planning the best re-refining process for a particular organization or locality. 


\section{EXHIBIT 7}

COMPARISON OF BERC CLAY CONTACTING, HYDROFINISHING AND ACID/CLAY METHODS OF LUBE OIL RE-REFINING

Predesign Process Equipment costs Total Fixed Cost

Working Capital

Total Capital Required

Total Payroll

Solvent costs

Direct Manufacturing Cost/Day

Indirect Manufacturing Cost/Day

Fixed Manufacturing Dost

General Expense

Total Manufacturing cost/Day

Cost, $\$$ /gallon, 20,570 gal/day

\begin{tabular}{|c|c|c|}
\hline Acid/Clay & $\begin{array}{c}\text { BERC } \\
\text { Hydrofinishing }\end{array}$ & $\begin{array}{l}\text { BERC Clay } \\
\text { Contacting }\end{array}$ \\
\hline$\$ 1,322,400$ & $\$ 1,890,000$ & $\$ 1,765,200$ \\
\hline $1,476,600$ & $2,079,000$ & $1,963,000$ \\
\hline 728,600 & 905,800 & 925,800 \\
\hline $2,205,200$ & $2,984,800$ & $2,888,800$ \\
\hline 184,800 & 226,400 & 184,800 \\
\hline 215,800 & 215,800 & 215,800 \\
\hline 7.930 & 6,158 & 6,583 \\
\hline 214 & 322 & 214 \\
\hline 548 & 773 & 729 \\
\hline 801 & 1,025 & 994 \\
\hline 9,493 & 8,278 & 8,520 \\
\hline 0.49 & 0.40 & 0.41 \\
\hline
\end{tabular}




\section{REFERENCES}

1. Richard J. Bigda Associates. Predesign Cost Estimate for Re-refined Lube Oil Plant. BERC/RI-77/11, June 1977 .

2. Whisman, M. L., J. W. Goetzinger, and F. O. Cotton. Waste Lubricating oil Research: Some Innovative Approaches to Reclaiming Used Crankcase Oil. Bureau of Mines RI 7925, 1974 .

3. Bethea, S. R., et al. To Hydrotreat Waste Lube Oil。 Hydrocarbon Processing. September 1973, p. 134.

4. Beuther, H., et al. Hydrogenation to Assume New Role in Lube oil Treating. Oil and Gas Journal. May 16, 1966 , p. 185 .

5. Gulfinishing. Hydrocarbon Processing. September 1976 , p. 141 .

6. Ferrofining. Hydrocarbon Processing, September 1976 , p. 137 .

7. Richard J. Bigda \& Associates. Comparison of BERC Rerefining Process with Acid/Clay Distillation Process. september 1977. 